\title{
BIOMASS AND PRODUCTIVITY OF THE SUBALPINE PINUS ALBICAULIS - VACCINIUM SCOPARIUM ASSOCIATION IN MONTANA, USA*
}

\author{
F. FORCELLA \& T. WEAVER
}

Department of Biology, Montana State University, Bozeman, Montana 59715, USA

\section{Keywords:}

Biomass, Pinus albicaulis, Productivity (net primary), Root mass, Subalpine forest, Vaccinium scoparium, Woodland

\section{Introduction}

Natural resource management has been and remains a significant problem in the western United States of America. In at least some geographic areas, vegetation classification is a constructive precursor to effective management. The values of a classification lie, in part, in their applicability to estimation of 'site potential', i.e. the potential taxa, productivity and stability of specific communities within the classificatory scheme. A significant portion of the Pacific Northwest's climax vegetation has recently been classified. Pfister (1976) lists all completed and on-going classifications (excepting Hickman 1976) in the western USA.

Now that these classifications are more or less complete, and with a management perspective in mind, what are the current and near future research priorities? In conjunction with continual reassessments of the classifications, we believe that they might include studies of (1) vegetation mapping. (2) vegetation change. (3) biomass and productivity and (4) nutrient cycling. That resource managers need immediate, coherent data, or at least best guesses from the research groups on these subjects has been

* Idiotaxonomy follows that of Hitchcock \& Cronquist (1973). There presently is no formal, Latinized syntaxonomical system for the Pacific N.W. of the USA.

The summer field work was funded by the Intermountain forest and Range Experiment Station, U.S. Forest Service, under Contract No. 12-11-204-12. Suppl. No. 33. Funds for computer analyses were generously provided by the Dept. of Biology. Montana State University, and S. Holland (University of California).

The authors thank J. V. Basile. J. Major, R. H. Rumely, the editors $H$. Lieth and $\mathbf{R}$. $H$. Whittaker, and a reviewer for Vegetatio for their helpful comments. clearly stated in a recent Institute of Ecology Report $[1974,4(3): 3]$.

Relatively little research has been published on the biomass and productivity of Rocky Mountain forests (Moir 1972, Johnstone 1971, Whittaker \& Niering 1975, Landis \& Mogren 1975, and Hanley 1976). This paper deals with the above-and belowground biomass and productivity of the Pinus albicaulis Engelm.-Vaccinium scoparium Leiberg association. Since we studied 14 stands, we were able to determine the range of values expected in typical stands, and relate some of the variance to stand basal area and age. The mass and production of each stand was not, however, studied in depth. Samples of stand components were taken from each stand and regression equations developed for prediction of mass and productivity (ultimately on a unit area basis). The validity of this approach is a function of the initial regression equation statistics. Though error is of course present in the equations, we feel that accurate predictions of biomass and reasonable estimates of productivity are possible. We hope that the results reported here will contribute to a basis for the management of these forests.

\section{The Pinus albicaulis-Vaccinium scoparium association}

An association, as we have used the word here, is the sum of easily recognized, floristically and structurally repetitive stands of vegetation. The term 'habitat type' has been adopted as a classificatory unit for land by several researchers in the Pacific Northwest. Though the inclusion of habitat into the definition of association (Flahault \& Schröter 1910, in Braun-Blanquet 1964) is appealing, we have avoided its use in this report because the abiotic factors of an organism's environment are not easily documented by field observations - except circularly through floristics 
and physiognomy.

The $P$. alhicaulis- $-F$. scoparium association is an easily recognized, geographically repeatable, subalpine forest of noncalcareous substrates in the northern Rocky Mountains. Its vegetation, soil, soil parent material and climate have been characterized by Weaver \& Dale (1974). The stands of this association are normally even-aged and may attain relatively great ages $(600$ years +$)$. The site index (tree height from time of establishment) is about $8 \mathrm{~m}$ at 100 years age. The understory is typically dominated by the low-growing $(10-30 \mathrm{~cm}) \mathrm{V}$. scoparium (Figure l). Vegetational change appears to be cataclysmic rather than 'successional' (cf. Loucks 1970). Fire scarred stumps and/or soil charcoal are always found in the stands. Avalanches and wind-throwing may also affect vegetation cycling in this association.

Tree seedling establishment under the arboreal canopy



Fig. I. A 150 year old Pinus alhicaulis-Vaccinium scoparium community. The trees are about $10 \mathrm{~m}$ in height and $20 \mathrm{~cm}$ dbh. Note the carpet of V. scoparium. and the absence of prominent herbs. The height of the shovel above the ground is about $1 \mathrm{~m}$. is meager. Occasionally, the few Ahies lasiocurpa individuals in the understory outnumber those of $P$. albicaulis. These small Ahies often result from the layering of an older tree. Both Daubenmire \& Daubenmire (1968) and Pfister et al. (1974) recognize an $A$. lasiocarpa ( $P$. alhicaulis)- $V$. scoparium habitat type. The dominance of $P$. alhicaulis in our stands might be due to (1) a very slow (600 years + ) successional replacement of $P$. alhicaulis by $A$. lasiocarpa. (2) physical (eg. climatic) limitation of Ahies on $P$. albicaulis sites, or (3) biological limitations to Abies such as ubiquity ( $100^{\circ}$ " constancy) of the Ahies pathogen Puccimiastrum geoppertianum (Boyce1961. Faull 1939) in the P. alhicaulis-V. scoparium association.

Though $P$. alhicaulis is not generally recognized for its merchantable qualities (until recently, see Day 1967, Kaspar \& Szabo 1970. Keenam et al. 1970), the $P$. alhicaulis- $V$. scoparium association is valuable for its aesthetic qualities. for wildlife food (large edible pine seeds, raccinium fruit and assorted forages; see Weckwerth 1971. Mealey 1975) and for watershed protection.

\section{Sampling methods}

\section{I'egctation}

Fourteen stands of the $P$. alhicaulis- 1 . scoparium association were sampled in 7 mountain ranges throughout southwestern Montana (the Madison. Tabacco Root. Elkhom, Big Belt. Little Belt. Castle and Absaroka Mountain Ranges). Each stand was sampled with three $6.67 \times 30 \mathrm{~m}$ (0.06 ha) plots which were placed parallel to the slope of the stand. All trees within these 200 sq.m plots were tallied by species into $5 \mathrm{~cm}$ dbh size-classes (trees less than $1.35 \mathrm{~m}$ height were considered seedlings). Shrub and herb coverages were estimated in $10^{\circ}{ }^{\prime}$, classes in sixty 1 sq.m quadrats which were placed in two contiguous $1 \times 30 \mathrm{~m}$ transects along the axis of each plot. These transects were large enough to encompass the contagious distribution of the shrubs (Forcella 1975). The canopy coverage of the tree layer was measured with a vertical periscope and was considered to be equal to the percentage of 30 points (at I $\mathrm{m}$ intervals) covered along the axis of each plot. The vascular plant species encountered within each plot were recorded, collected and filed at the Herbariam. Montana State University.

\section{Biomass and productivity}

The aboveground portions of $34 P$ albicaulis trees, $1-37 \mathrm{~cm} \mathrm{dbh}, 1.35-18.0 \mathrm{~m}$ height and representative of the 
stands in which they grew, were felled, sectioned into component parts, and weighed in the field with handheld scales. The roots wider than $1 \mathrm{~cm}$ diameter of 9 trees were excavated and weighed also. Sections of each component part of the tree were wrapped in polyethylene and transported to the laboratory for annual ring width, ring number and wet weight/dry weight analyses. Samples were oven dried at $60 \mathrm{C}$ to constant weight. Wood (xylem) production of 26 of the trees was estimated by calculation of the mean annual parabolic volume increment and conversion to mass increment by the density factor of $0.42 \mathrm{~g}_{\mathrm{cm}} \mathrm{cm}^{3}$ (Peattie 1953, Keenam et al, 1970). Radial increments used in calculating volume increment were the annual (1969-1973) means measured at 8 equidistant circumferential points, perpendicular to the axis of growth on dbh cross-sections. Radial increments of bole crosssections above breast height were not analyzed consistently: where they were measured, they compared favorably with those at $1.35 \mathrm{~m}$. A sample of leafy twigs from each of 16 trees was divided into annual increments for determination of leaf production and longevity. Phloem and bark production were not measured directly. The combined production of these two tissues was estimated through a series of assumptions described in Appendix 1. Briefly, there appears to be a linear relationship between bark mass and tree basal area (BA). Hence changes in BA (annual increment) will have corresponding increments in bark mass (annual production).

At the end of the 1974 growing season, twenty-nine 0.5 sq.m quadrats of the understory vegetation were clipped from several of the stands to estimate understory biomass and production. Twig and leaf production of $V$. scoparium were estimated by separation of the leaves and current twigs from the main shoots: these plant parts were then dried at $60 \mathrm{C}$ and weighed. Diameter increments of the numerous small (less than $2 \mathrm{~mm}$ diameter) woody shoots of this shrub are small; and because of the shrub's low stature $(10-30 \mathrm{~cm})$, the mass increment of these stems is probably minute (cf. Andreyashkina \& Gorchakovskii 1972) and was not measured, but it was estimated from the work of Whittaker \& Woodwell (1969) as described later. The dead twig mass of $V$. scoparium was measured separately. Herbaceous production was considered equal to its standing crop, though some ephemerals were senescent at the sampling date.

For a simple estimate of biomass of roots and rhizomes less than $1 \mathrm{~cm}$ diameter, eleven 1 sq.m quadrats from 5 stands were excavated to $0-10$ and $10-40 \mathrm{~cm}$ depths. These soil depth-intervals were chosen because the rhizomes of
I. scoparium are confined entirely to the upper $10 \mathrm{~cm}$ of soil, and root material was not readily apparent below $40 \mathrm{~cm}$. All roots and or rhizomes greater than $1 \mathrm{~mm}$ diameter were sieved from the soil and separated by species. To estimate the mass of fine roots $(<1 \mathrm{~mm})$ the sieved soil was evenly redistributed throughout the excavation and 1,16 of it (to both 10 and $40 \mathrm{~cm}$ depths) was transported to the laboratory for further sieving and washing: these roots were not separated by species

\section{Regressions, estimates and stand totals}

Untransformed and logarithmic (base 10) transformations of the biomass and production data were regressed against the easily measured plant parameters, dbh and shrub coverage. The estimates obtained from the resulting regression equations were substituted for original stand data (tree density by size class, or shrub coverage) to determine mass and production on a unit area basis. For tree species other than $P$. albicaulis, and for the few individuals of $P$. albicaulis greater than $37 \mathrm{~cm}$ dbh in the samples plots, the biomass regression equations of Weaver \& Forcella (1977) were used. The productivity-dbh equations were extended somewhat beyond their data limits ( $P$. albicaulis, $1-37 \mathrm{~cm} \mathrm{dbh)} \mathrm{to} \mathrm{account} \mathrm{for} \mathrm{the} \mathrm{trees}$ mentioned above.

The independent variables used in the regressions were chosen for their ease of field and laboratory measurement and were not necessarily those that gave the best fit to the data. For example, the independent variable $\mathrm{dbh} \times$ tree height' gives a slightly better fit to regressions of mass and production than simple 'dbh'. However, dbh was used for correlation with these data because it was not feasible to make height measurements for every tree in every stand.

After unit area mass and production were calculated for each stand, the two sets of variables were regressed against stand basal area and arboreal canopy coverage, and median shrub coverage for the tree and shrub synusiae respectively.

There is an inherent bias in logarithmic, sum of least squares regressions due to the skewed distribution of the (arithmetic) squared deviates around the mean regression line (Baskerville 1972, Beauchamp \& Olson 1973). The antilogarithmic conversion of the regression equation to arithmetic units should thus result in systematic underestimation. Brownlee (1967, as cited by Baskerville 1972) provides a method for correcting the arithmetic estimates. 'Corrected' estimates of $P$. albicaulis data were graphically compared to the original regression estimates and to the original data. The degree of difference between the cor- 
rected and original estimates is a function of the magnitude of the squared deviations of the original data. In poorly correlated regressions (leaf mass-dbh) the difference between the corrected and original estimates is large, but this is likely due to the high variation in mass of component parts of the largest sampled trees (Whittaker et al. 1974). In highly correlated regressions (aboveground mass-dbh), corrected estimates appear to overestimate the original data significantly. Madgwick \& Sa too (1975) compared the actual standing crops to 'corrected - unbiased' logarithmic regression estimates, of very small forest stands. The corrected regression estimates consistently overestimated the actual standing crop (ibid., Table 3, p. 1449).

Corrected logarithmic regression estimates have not been used in this report and the resulting calculations might therefore be considered mean to minimal estimates.

\section{Results and discussion}

Vegetation

P. albicaulis always provided over $75^{\circ}{ }_{10}$ (usually $85-100^{\circ}{ }^{\circ}$ ) of the basal area (BA) in the stands studied; other contributors were old 'wolf trees of Pinus contorta latifolia and infrequent individuals of Abies lasiocarpa and Picea engelmannii. Mean BA's for the stands ( 3 plots'stand) range from 25 to $108 \mathrm{sq} . \mathrm{m} /$ ha (c.v. $20^{\circ}{ }_{0}$ or less). This range of $\mathrm{BA}$ is similar to that of many mature Rocky Mountain forests studied by Daubenmire \& Daubenmire (1968) and Whittaker \& Niering (1975), but smaller than stands of the Tsuga heterophylla series $(100-500 \mathrm{sq} . \mathrm{m} / \mathrm{ha}$, Daubenmire \& Daubenmire 1968) and of the Pacific Coast forests $(100-300+$ sq.m/ha, Franklin \& Dyrness 1973. Westman \& Whittaker 1975). Canopy coverage of the

Table 1. Individual tree and stand biomass and productivity regression statistics for Pinus albicaulus and associated species. Equations are in the forms: $y=q+b x$ and $y=a+b \log _{10} x$.

\section{REGRESSION STATISTICS}

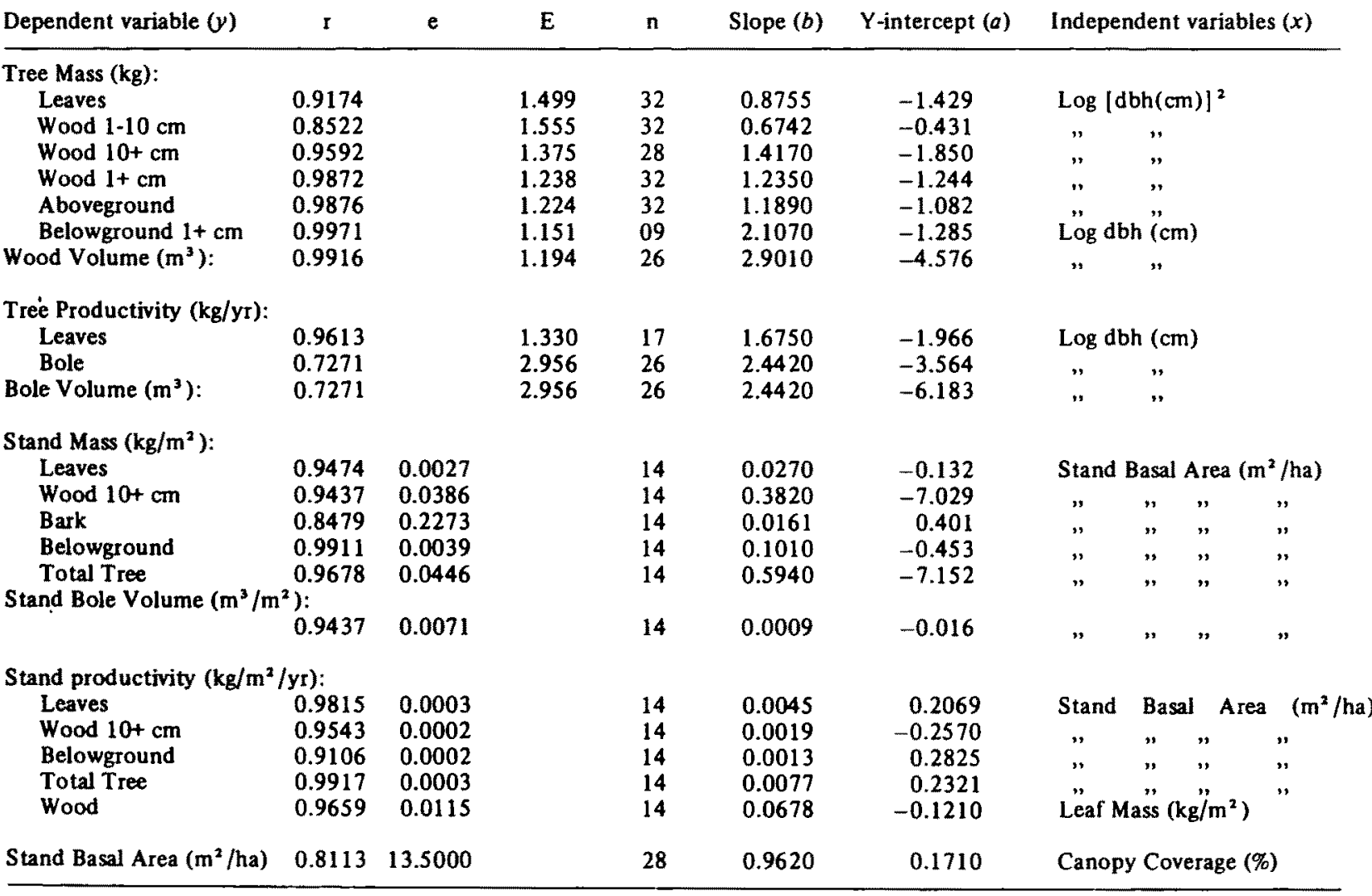


tree layer ranged from 36 to $95^{\circ}{ }_{\circ}$ (c.v. $25^{\circ}{ }_{\circ}$ or less) and was correlated with BA $(\mathrm{r}=0.81$. Table 1$)$. Such open cancpies suggest 'woodland' conditions, but as will be shown later, tree densities and biomasses are suggestive of a forest association.

Median coverage of Vaccinium scoparium ranged from 12 to $67^{\circ}{ }^{\circ}$ (cf. Weaver \& Dale 1974). These shrubs are distributed in patches on the forest floor (Forcella 1975). and stands on steep $\left(35^{\circ}{ }_{0}+\right)$ ) slopes support considerably less $V$. scoparium than those of more level topography (slope vs. coverage, $r=-0.50$ ). This lack of shrub coverage, in small patcies or entire stands, may be due to snow drifts (Knight 1975), snow movement, or solifluction.

Herb coverage was generally less than $5^{\circ}{ }_{\circ}$ and was not noticeably correlated with shrub coverage, though the differing phenologies of the taxa may 'obscure /any relationship. Herbaceous species with high constancies were: Arnica latifolia $93^{\circ}$, Carex rossii $71 \%^{\circ}$, Lupinus argentea $64^{\circ}$, C. geveri $57^{\circ}$. Poa nervosa $57^{\circ}$, Hieracium gracile $57^{\circ}$, Epilohium angustifulium $57^{\circ} \mathrm{m}$, Potentilla diversifolia ssp. dicersifolia $50^{\circ}{ }_{0}$ and $A$. cordifolia $50^{\circ}{ }_{0}$. The shrub, Juniperus communis ssp. montana, with negligible cover, occurred in $57^{\circ}$ of the stands. No annual species were observed in our stands.

\section{Regressions}

The biomass and productivity regressions generated for $P$. albicaulis are remarkably similar to those of taxa presented by Whittaker et al. (1974). Whittaker \& Woodwell (1968) and Weaver \& Forcella (1977). The regression statistics. independent variables and number of data points for all regressions used are listed in Tables $/$ and 2 . The correlation coefficients range from 0.72 to 0.99 and all are significant at the $99^{\circ}{ }_{\text {o }}$ level. Better evaluations of regression error are made with the standard error ' $e$ ' for simple regressions and the relative error of the estimate ' $E$ ' for logarithmic regressions (Whittaker \& Woodwell 1968).

\section{Tree mass}

Tree size within our stands ranged from seedlings to individuals with breast height diameters of $55-60 \mathrm{~cm}$. The biomass of the largest tree was: aboveground $1367 \mathrm{~kg}$. belowground $266 \mathrm{~kg}$, leaves $112 \mathrm{~kg}$ and merchantable bole (10 cm + diameter) $961 \mathrm{~kg}$.

The arboreal masses per sq.m were calculated by summing the estimated masses of individual trees in the sample plots. The resulting summations were well correlated with stand basal area (Figure 2, Table 1). The fact that basal area is also correlated with canopy coverage (Table 1) suggests that aerial photographs might be used

Table 2. Individual quadrat $\left(1 \mathrm{~m}^{2}\right)$ and stand biomass and productivity regression statistics for Vaccinium scoparium. Equations are in the form: $y=a+b x$

\section{REGRESSION STATISTICS}

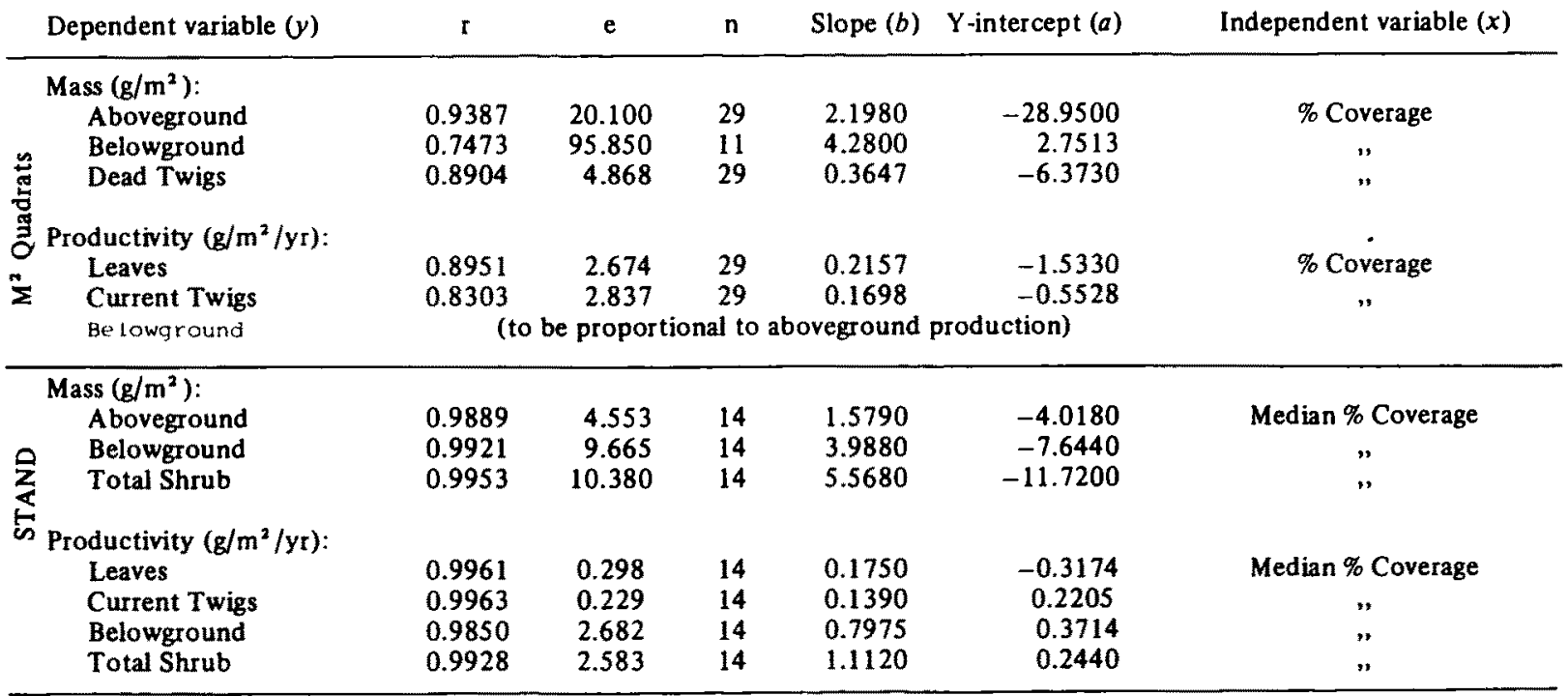



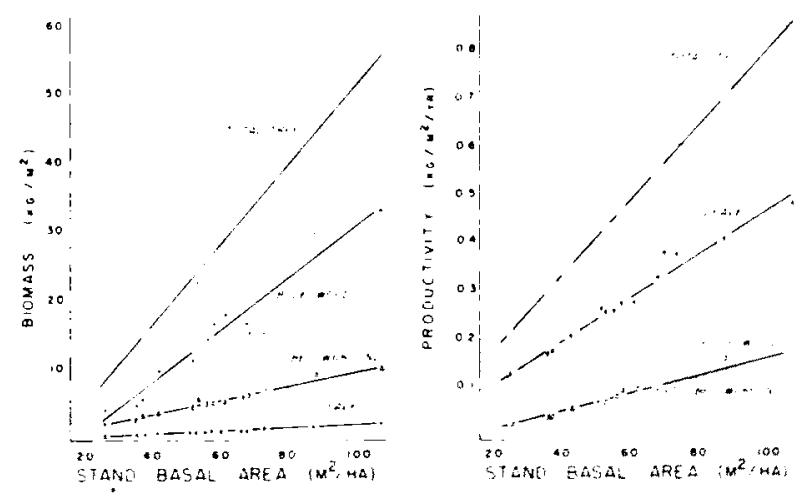

Fig. 2. The biomass and productivity of $P$. alhicaulis stands in relation to stand basal area.

to estimate biomass (and productivity). at least in arboreal vegetation with relatively open canopies.

The range of arboreal aboveground mass in the 14 stands was 8.4 to $47.2 \mathrm{~kg} / \mathrm{sq} . \mathrm{m}$. The ranges of stand volume, merchantable $(10 \mathrm{~cm}+)$ bole mass, bark mass and leaf mass were $12.3-80.8 \mathrm{dm}^{3} / \mathrm{m}^{2}, 5.0-33.7 \mathrm{~kg} / \mathrm{m}^{2}, 0.7-2.0$ $\mathrm{kg} / \mathrm{m}^{2}$ and $0.7-2.8 \mathrm{~kg} / \mathrm{m}^{2}$ respectively (Figure 2 ).

The variation (or $\mathrm{e}$ ) of the leaf mass $/ \mathrm{m}^{2}$ of basal area regression is small compared to those of total tree or bole wood regressions (Table 1), but simple leaf mass dbh regressions for individual trees have typically high variability. Might this indicate that the forest canopy is more internally consistent than, and somewhat independent of, its supporting woody structures? Leaf mass is well correlated with the current functional vascular tissue of single plants and stands (Shinozaki et al. 1964). Leaf mass and wood production are correlated in P. alhicaulis stands also (Table 1).

The mass of major roots $(1 \mathrm{~cm}+)$ range from 2.6-10.4 $\mathrm{kg} / \mathrm{m}^{2}$. The mean mass of $P$. albicaulis roots $0.1-1.0 \mathrm{~cm}$ diameter in the eleven $1 \mathrm{~m}^{2} \times 0.4 \mathrm{~m}$ excavations was $0.4 \mathrm{~kg} / \mathrm{m}^{2}$ (s.d. $=0.18$ ). The mean mass of fine roots (less than $1 \mathrm{~mm}$, species composition unknown) was $0.5 \mathrm{~kg} / \mathrm{m}^{2}$ $(\mathrm{s} . \mathrm{d} .=0.18)$. The root mass of the two finer diameter classes was approximately evenly distributed between the two soil depths $(0-10$ and $10-40 \mathrm{~cm})$. There was no correlation of root mass with the distance of the excavation to the nearest tree, or with the above- or belowground mass of $l$. scoparium. The root to shoot biomass ratio is consistently $1: 4$ for the tree synusia. Temperate forest ratios are generally $1: 5$, and woodlands $1: 4$ (Rodin \& Bazilevich 1967, Whittaker \& Marks 1975).
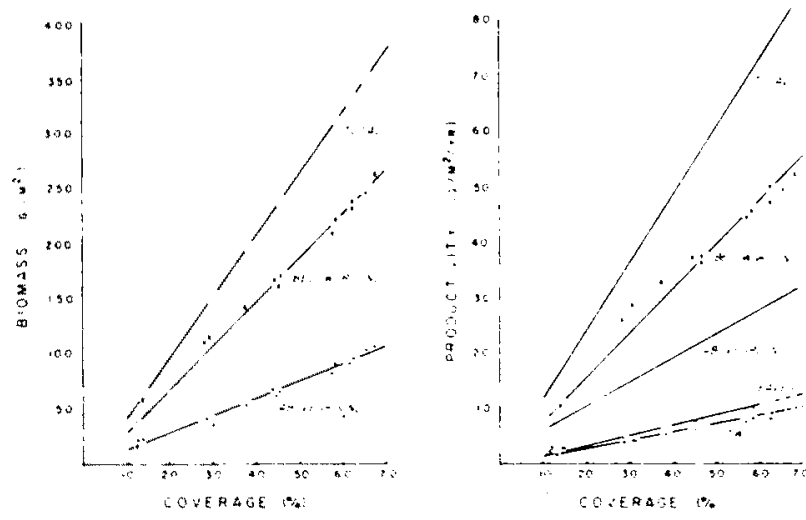

Fig. 3. The biomass and productivity of $l$. scopurium in $P$. albicaulis stands in relation to median shrub coverage. Aboveground wood productivity has been estimated as described in the text.

Understory biomass

Shrub coverage in the sq.m quadrats ranged from 0 to $100{ }^{\prime}{ }_{0}$. Above- and belowground mass for a quadrat with $100^{\prime \prime}$ "coverage was 191 and $425 \mathrm{~g} / \mathrm{m}^{2}$ respectively. Herbaceous standing crops (= production) varied. but were small and averaged less than $10 \mathrm{~g} \cdot \mathrm{m}^{2}$.

The mass of the shrub-herb layer the mean of the averages for three plots per stand) ranged from 23-109 $\mathrm{g} \mathrm{m}^{2}$ for the aboveground parts. and $20264 \mathrm{~g} \mathrm{~m}^{2}$ for the belowground ( $>1 \mathrm{~mm}$ diameter) portions (Figure 3 ). The regression equations used for the mass of $I$. scoparium appear to also predict the aboveground weight of $V$. myrtillus, a similar species, in Finland (Mälköene 1975). The below- to aboveground ratio for this synusia is $2.0-2.5: 1.0$, which is nearly identical to the ratios for I'. raccilluns and Gaylussacia haccata (Whittaker \& Marks 1975). This ratio for the understory, however, is strikingly different from that of the tree layer: one might speculate that selection for these contrasting 'storage' strategies involved ground fire, animal browsing and competition for light.

\section{Total masses}

Total aboveground biomass for both the arboreal and shrub-herb synusia ranged from $8.5-47.4 \mathrm{~kg} / \mathrm{m}^{2}$. Total belowground mass was $3.7 .11 .3 \mathrm{~kg} / \mathrm{m}^{2}$. Total stand biomass ranged from $12.2-58.8 \mathrm{~kg} \mathrm{~m}$ m $^{2}$. Our older stands are surprisingly massive. Published reports of forest stands with greater masses of which we are aware are: Applachian cove forests (Whittaker 1966) with $60 \mathrm{~kg} / \mathrm{m}^{2}$ aboveground; tropical rain forests (Rodin \& Bazilevich 1967) with $75+\mathrm{kg} / \mathrm{cm}^{2}$ total: Thuja plicata and Abies grandis stands in northern Idaho (U.S.A.; maritime 
influence) with up to $93 \mathrm{~kg} / \mathrm{m}^{2}$ (Hanley 1976): and mesic northeastern Pacific Coast Tsuga heterophylla-Picea sitchensis (Grier \& Logan 1975). Pseudotsuga menziesii and Sequoia semperiirens (Franklin \& Dymess 1973) forests with aboveground weights of 87.177 , and $270 \mathrm{~kg} / \mathrm{m}^{2}$ respectively.

\section{Tree productivity}

Annual productivity for the largest trees in our stands (55-60 $\mathrm{cm} \mathrm{dbh)} \mathrm{was:} \mathrm{bole} \mathrm{wood.} 6 \mathrm{~kg}\left(14 \mathrm{dm}^{3}\right)$ : leaves, $10 \mathrm{~kg}$ : and belowground (estimated to be directly proportional to aboveground production on a biomass basis). $3 \mathrm{~kg}$.

Annual leaf production was normally $12{ }^{\circ}{ }_{0}$ of the total leaf mass for individual trees. Leaves lived for more than 13 years in many cases. About $30^{\circ}$ of the leaf mass had dropped after 6 years age, and $85^{\circ}{ }^{\circ}$ after 8 years. Similar leaf longevity was reported for a subalpine stand of Abies mariesii and A, teitchii in Hokaido (Kimura 1963). Grime (1966) suggests that long leaf persistence is correlated with high environmental stress.

Stand wood production, found by summing the productivities of trees present in sample plots, was 32-180 $\mathrm{g} / \mathrm{m}^{2} / \mathrm{yr} \quad\left(=0.08-0.42 \mathrm{dm}^{3} / \mathrm{m}^{2} / \mathrm{yr}\right)$. Bark production of P. alhicaulis was about $1-7 \mathrm{~g} / \mathrm{m}^{2} / \mathrm{yr}$ (Appendix 1). Leaf productivity for the tree layer ranged from $133-475 \mathrm{~g} / \mathrm{m}^{2}$, $\mathrm{yr}$, and the belowground productivity estimates were from $50-144 \mathrm{~g} / \mathrm{m}^{2} / \mathrm{yr}$ (Figure 1).

We have estimated a 6-8 year ovulate cone and seed production sequence in $28 \mathrm{P}$. albicaulis stands which include the 14 stands discussed here (Forcella \& Weaver 1977). Average cone and seed production for the 14 stands considered here range from $25-84$ and from $8-27 \mathrm{~g} / \mathrm{m}^{2} / \mathrm{yr}$ respectively. Average annual cone production is better correlated with (and is probably a function of stand canopy coverage than with any other stand characteristic measured. Though there is wide variation among the stands, cone and seed productivity represent about 9 and $3 \%$ of total tree production.

Of total tree production $\left(229-890 \mathrm{~g} / \mathrm{m}^{2} / \mathrm{yr}\right)$, about $55 \%$ (s.d. $=3.6)$ is devoted to the leaves; the leaf production to aboveground wood production ratio is about 3.5 , and smaller stands have a slightly greater ratio than the larger stands. The funnelling of photosynthate to new leaves was also observed in Betula pubescens $\left(60^{\circ}\right)$ in Greenland (Elkington \& Jones 1974), and the phenomenon may be characteristic for treeline forests. In contrast to the stress environment species, the generally slow growth of woody plant seedlings may be due to channelling of photosynthate to wood rather than leaf production (Grime \& Hunt 1975). In temperate forest trees the photosynthetic product channelled into wood production also equals or exceeds that which is used for leaf production (Weaver 1975. Rodin \& Bazilevich 1967).

\section{Understory productivity}

Maximum shrub productivity for a sq.m quadrat $\left(100^{\circ}\right.$, coverage) was : leaves and twigs, $37 \mathrm{~g} / \mathrm{yr}$; and belowground (estimated as with tree roots), $81 \mathrm{~g} / \mathrm{yr}$.

The range of average productivities for the shrub synusia was: leaves. $3-12 \mathrm{~g} / \mathrm{m}^{2} / \mathrm{yr}$ : and current twigs. $2-10 \mathrm{~g} / \mathrm{m}^{2}$ yr (Figure 3). Stem wood increment was not measured in $V$. scoparium, but since biomass and productivity ratios for Gay/ussacia haccata (Whittaker \& Woodwell 1969) and $l$. scoparium are nearly identical for organ systems measured on each, we based our stem productivity estimates on the branch wood and bark production to aboveground mass ratio of $G$. haccata $(0.086)$. Productivity of stem tissue in $V$. scoparium. which lacks a main stem, would then be $2-9 \mathrm{~g} / \mathrm{m}^{2} / \mathrm{yr}$. Total aboveground woody production for the shrub is $419 \mathrm{~g}^{2} \mathrm{~m}^{2} / \mathrm{yr}$. The belowground productivity estimates for the shrub layer range from $4-79 \mathrm{~g} / \mathrm{m}^{2} / \mathrm{yr}$.

\section{Total producticity}

Total aboveground productivity of all synusiae ranged from $208-752 \mathrm{~g} / \mathrm{m}^{2} / \mathrm{yr}$. Fine root productivity, not considered above, was assumed to equal $10^{\circ}{ }^{\circ}$ of its mass, i.e. $51 \mathrm{~g} / \mathrm{m}^{2} / \mathrm{yr}$. The range of total belowground productivity was $168-267 \mathrm{~g} / \mathrm{m}^{2} \mathrm{yr}$. Thus total stand productivity ranges from $381-951 \mathrm{~g} / \mathrm{m}^{2}$ iyr (the above figures are not additive). Such productivities are relatively low for temperate forests, but are probably typical for temperate woodlands (Whittaker \& Marks 1975, Rodin \& Bazilevich 1967). Kimura's (1963) subalpine Abies stand produced $1100 \mathrm{~g} / \mathrm{m}^{2} / \mathrm{yr}$, and the arctic treeline Betula pubescens $207 \mathrm{~g} / \mathrm{m}^{2} / \mathrm{yr}$ (Elkington \& Jones 1974)

The mean below- to aboveground productivity ratio for $P$. alhicaulis trees is 0.25 (s.d. $=0.03$ ); the more massive stands have ratios less than the mean. Weaver (1975) has shown that root-shoot ratios decline as oak trees age. Kimura (1963) reports a productivity ratio of 0.30 for a single Ahies stand, and Bray (1963) calculates a ratio of 0.21 for arboreal species in general. The belowground/ aboveground productivity ratio for all stand components, including shrubs, fine roots, etc., is $0.50( \pm 0.12)$; again, the more massive stands, especially those with little $V$. scoparium cover, are those with ratios less than the mean. 
The shrub-herb and fine root components play a significant role in stand dynamics. In young stands the productivity of the shrub-herb layer may approach $25^{\circ}$ of total stand production, though its corresponding biomass is normally less than $2^{\prime \prime}$ of the stand total.

\section{Stand age is. mass and productitity.}

In contrast to the good empirical mass or productivity basal area' relationship (Figure 2 ), stand age is a relatively poor predictor of arboreal mass and production (Figure 4). Cone production of $P$. albicaulis fluctuates widely between years (Forcella \& Weaver 1977), and variable seed crops

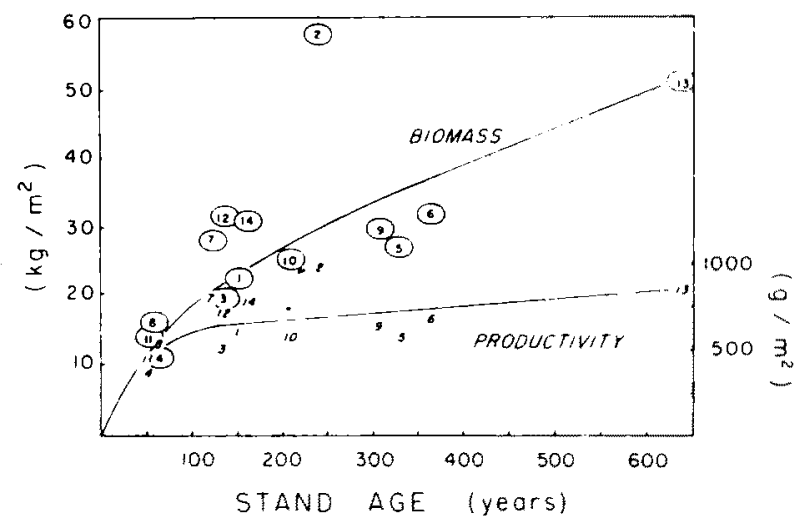

Fig. 4. The biomass and annual productivity of $P$. albicaulis stands in relation to the age of the stand.

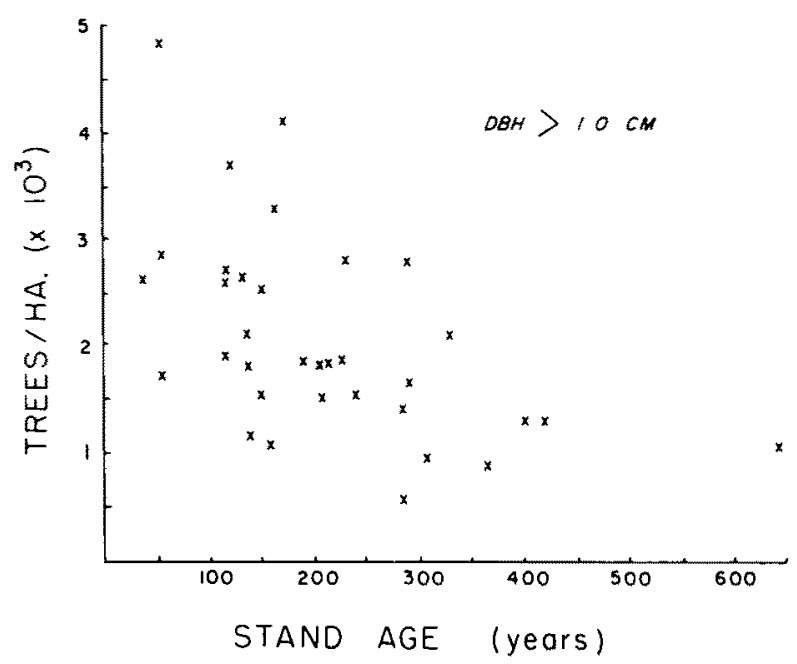

Fig. 5. The density of trees ( $>1 \mathrm{~cm} \mathrm{dbh}$ ) in $P$. albicaulis stands in relation to the age of the stand. Data for 19 of these stands were taken from Weaver \& Dale (1974). may play an important role in the initial establishment of a stand. Extremely high variation of tree density in stands of similar age may be a result of this: Figure 5 incorporates the field data of Weaver \& Dale (1974) with that of our study to show the possibility of 5-fold differences in stand densities of trees greater than $1.0 \mathrm{~cm}$ dbh in 50 year old stands. Figure 5 also indicates that high density variations persist, though they progressively decrease to an age of about 400 years. Basal area, biomass and productivity are in part a function of tree density (Spurr 1952), and the high variation in density may partially explain the poor mass age relationship. The great mass of Stand 2 ( 240 years old) cannot, however, be explained by density alone. Analysis of increment cores from this stand reval a high growth rate (annual radial increment greater than $1.5 \mathrm{~mm}$ ) until the year 1850. At that time there was an abrupt reduction in growth (annual radial increment $0.27 \mathrm{~mm}$, s.d. $0.08 \mathrm{~mm}$ ) that has continued to the present; growth is now similar to that of trees in older $P$. alhicaulis stands. Productivity estimates for this stand are therefore probably reasonable.

\section{Conclusions}

Within the Pinus alhicaulis-Vaccinium scoparium association one may estimate the biomass and productivity of individual trees or shrubs within quadrats from measurements of their dbh or coverage respectively. Similarly, mass and production on a unit-area basis can be estimated from measurements of stand basal area and median shrub coverage.

Considering the physiographic position of the stands, their short frost-free season ( 32 days, Weaver \& Dale 1974) and data available in the literature for 'temperate" forests. it is surprising that $P$. albicaulis forests accumulate standing crops up to $58.8 \mathrm{~kg} / \mathrm{m}^{2}$ with annual productivities as large as $951 \mathrm{~g} / \mathrm{m}^{2}$. Forest biomass usually tends to peak at mesothermal elevations in mountainous systems (Whittaker 1963, Whittaker \& Niering 1975, Yoda 1968). We have relatively little data for systematic comprisons of our stands to lower forests in the northern Rockies (Weaver \& Forcella 1977), but in conjunction with our field observations, these data suggest to us that $P$. albicaulis forests have the potential, under existing conditions, of being the oldest and most massive forests in the area (excepting giant Thuja-Tsuga and Abies forests, Hanley 1976). How and why such immense masses accumulate remains an enigma for us. $P$. albicaulis forests do not exist in 


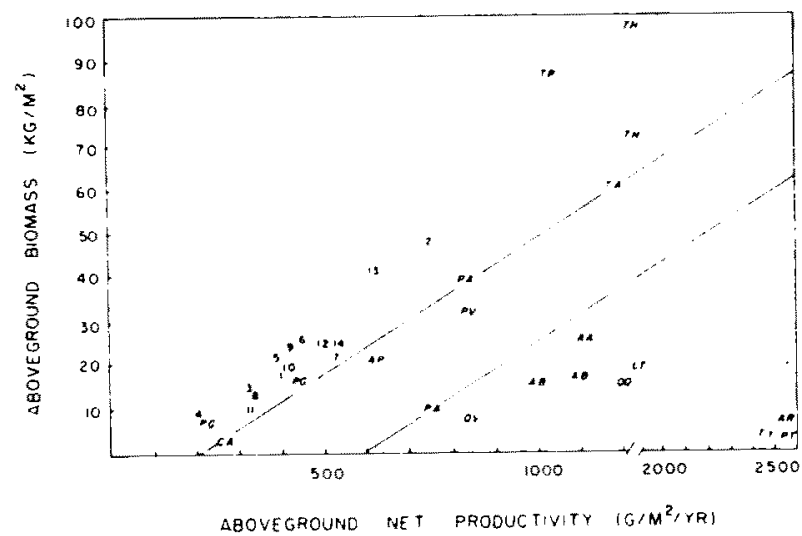

Fig. 6. A comparison of biomass accumulation ratios both within the $P$. alhicaulis- $V$, scoparium association and between several vegetation types. The area between the two oblique parallel lines represents the biomass accumulation ratio range for temperate vegetation (from Whittaker et al. 1974). $P$. albicaulis. $V$. scoparium 1-14: $P$. contoria-V. mirtillus PV. $P$. contorla-Geranium fremontii PG (Moir 1972): Almus ruhra AR (Zavitkowski \& Stevens 1972): Quercus sp. QQ (Johnson \& Risser 1975): Typha TY. Pleridium PT (Westlake 1963): Tsuga-Picea TP (Grier \& Logan 1975): Pinus-Rhododendron PR. Cupressus-Arctostapylos CA, Acer-Belula AB. Picea-Ahies PA. Tsuga-Acer TA, Lireodendron tulipifera LT, Acer-Aesculus AA. Ahies-Picea AP. Quercus-Vaccinium QV (Whitlaker et al. 1974): Thuja plicala-Pachistima myrsinites TH (17500 and $13800 \mathrm{~g} / \mathrm{m}^{2} / \mathrm{yr}$. Henley 1976 ).

especially favorable sites; they are often on ridge tops and their psammeptic soils are not particularly fertile (Weaver \& Dale 1974). The high and relatively moist sites of these forests do not exclude them entirely from forest fires, but they may reduce the frequency of the holocausts sufficiently to allow attainment of great age and biomass.

Inter- and intravegetational comparisons of aboveground biomass accumulation ratios (Figure 6) suggest: (1) relatively low production in the $P$. albicaulis stands, (2) the necessary increase in biomass accumulation ratios (32 to 69) from the least to most massive stands, and (3) a wide range in the data. The third suggestion requires elaboration. The biomass and production of forest stands within one vegetation type (association) vary greatly among themselves, due to age, disturbances, slight habitat differences etc. Thus statements about forest masses and production based on the analysis of a single 'mature (near) climax' stand, no matter how detailed the analysis may be, are as inconclusive as statements concerning any other population based on a sample number of one. Our stands, all of which came from what we believe to be the same plant association, may serve as an example; omitting the three youngest, they were originally chosen as mature representatives of the $P$, albicaulis- $V$. scoparium association, but they varied widely in age $(\times 4)$, biomass $(\times 3)$ and productivity $(\times 2)$.

Neither the traditional (hypothesized) logistic biomass age curve nor the optimal yield (rise and decline) productivity - age relationship is apparent in our data. On a unit-area basis, plant biomass continually increases with age, to at least an age of 640 years, whereas net primary productivity reaches a nearly stable level after about 150 years.

\section{Appendix 1}

Up to an age of 75 years the bark of $P$. alhicaulis remains smooth and about $3 \mathrm{~mm}$ thick over the entire surface of the bole. Assuming that a smooth bark indicates a lack of bark shedding. then all the bark produced by a tree remains on that tree. The mass of a tree's bark is easily measured by estimating its volume from the difference of total bole volume and bole wood volume. and multiplying by bark density (about $0.8 \mathrm{~g} / \mathrm{cm}^{3}$. c.v. $14^{\circ}{ }_{0}$ )

The mass of bark in a stand is linearly related to stand basal area (BA, Table 1), and ranges from 0.69 to $2.03 \mathrm{~kg} / \mathrm{m}^{2}$ in the 14 stands studied. The regression coefficient or slope $(\mathrm{b})$ of this relationship is the increase of bark mass per unit area increase of $\mathrm{BA}$. If the yearly basal area increment (BAI) is known, then annual bark mass increment ( = production) may be calculated:

$\mathrm{BAI} \times \mathrm{b}=$ bark production

Annual BA increment is calculated by dividing the annual wood volume increment by the slope of the stand bole volume over $\mathrm{BA}$ regression (Table 1); this slope is essentially a weighted mean height increment per unit BA increment. Annual BA increments in the stands range from 0.09 to $0.48 \mathrm{~m}^{2} / \mathrm{ha} / \mathrm{yr}$ with a corresponding bark production of 1 to $7 \mathrm{~g} / \mathrm{m}^{2} / \mathrm{yr}$. These production figures appear small, though if they are multiplied by the age of the stand, the products are often twice the calculated bark mass : about what one would expect considering that when a stand was younger, it probably produced less than it currently does. In some instances the "production $\times$ age" products are about equal to bark mass, thus the production estimates are certainly biased toward the low side in such cases. Of course. these bark production figures are also skewed toward low values due to our assumed absence of bark shedding. All in all, these values likely represent minimal but reasonable estimates.

\section{References}

Andreyashkina, N. I. \& P. O. Gorchakovskii. 1972. The productivity and methods of its assessment, of shrub, dwartshrub and herbaceous communities of the forest tundra. Ekologiya 3: 5-12.

Baskerville, G. L. 1972. Use of logarithmic regression in the estimation of plant biomass. Can. J. For. Res, 2: $49-53$. 
Boyce, J. S. 1961. Forest Pathology. McGraw-Hill. N.Y. 572 pp. Beauchamp. J. J. \& J. S. Olson. 1973. Corrections for bias in regression estimates after logarithmic transformation. Ecology $54: 1403 \cdot 1407$

Braun-Blanquet, J. 1964. Pflanzensoziologie. Springer-Verlag. Wien/New York. 865 pp.

Bray. J. R. 1963. Root production and the estimation of net productivity. Can. J. Bot. 41:65-72.

Daubenmire, R. \& J. B. Daubenmire. 1968. Forest vegetation of Eastern Washington and Northern Idaho. Wash. Agr. Exp. Sta. Tech. Bull. 60.104 pp

Day. R. J. 1966. Whitebark pine in the Rocky Mountains of Alberta. For. Chron. 43:278 284.

Elkington. T. T. \& B. M. G. Jones. 1974. Biomass and primary productivity of birch (Betula pubescens s. lat.) in South-West Greenland. J. Ecol. 62:821 $-8,30$.

Faull, J. H. 1939. A review of the extension of our knowledge of Calyptospora goeppertianum Kuehne. J. Arnold Arboretum 20:104 113 .

Forcella. $F$. 1975. A nonparametric method for the detection of pattern in vegetation. Mont. Acad. Sci. Proc. 35: $38-34$.

Forcella, F. \& T. Weaver 1977. Cone crops in whitebark pine forests (in review)

Grier, C. C. \& R. S. Logan. 1975. Biomass. productivity and nutrient distribution and cycling in a conifer forest on the Oregon Coast. Northwest Sci., Program and Abstracts, 47th Annual Meeting.

Grime. J. P. 1966. Shade avoidance and tolerance in flowering plants. In: R. Bainbridge. G. C. Evans \& O. Rackham (eds.). Light as an Ecological Factor. pp. 281 - 301. Blackwell Scientif, Publ. Oxford.

Handley, D. P. 1976. Tree biomass and productivity estimated for three habitat types of Northern Idaho. U. Idaho For. Wildl and Range Exp. Stn. Bull. 14, Moscow, Idaho. 15 pp.

Hickman, J. C. 1976. Non-forest vegetation of the Central Western Cascade Mountains of Oregon. Northwest Sci. 50: 145155

Grime. J. P. \& R. Hunt. 1975. Relative giowth rate: its range and adaptive significance in a local hora. J. Ecol. $63: 393-422$.

Hitchcock. C. L. \& A. Cronquist. 1973. Flora of the Pacific Northwest. Univ. of Washington Press. Seattle. $730 \mathrm{pp}$.

Johnson, F. L. \& P. G. Risser, 1974. Biomass, annual net primary production and dynamics of six mineral elements in a post oak-blackjack oak forest. Ecology 55: 1246-1258.

Johnston. W. D. 1971. Total standing crop and three component distribution in three stands of 100 year-old lodgepole pine. In: Young. H. E. (ed.). Forest Biomass Studies. U. Maine Agric. Exp. Sta., Orono.

Kimura. M. 1963. Dynamics of vegetation in relation to soil development in Northern Yatsugatake Mountains. Jap. J. Bot. 18: 255-287.

Kaspar, J. B. \& T. Szabo. 1970. The physical and mechanical properties of whitebark pine. Forest Chrom. 46: 314-316.

Kira, T. \& T. Shidei. 1967. Primary production and turnover of organic matter in different forest ecosystems of the Western Pacific. Jap. J. Ecol. 17: 70-87.

Keenan, F. J. et al. 1970. Mechanical properties of Pinus albicaulis. Forest Chron. 46: 322-325.
Knight. D. H. 1975. The potential sensitivity of various ecosystem components to winter precipitation management in the Medicine Bow Mountains. Wyoming. Dept. Bot., U. Wy oming. Laramie. $376 \mathrm{pp}$.

Landis. T. D. \& E. W. Mogren. 1975. Tree strata biomass of subalpine sprucefir stands in Southwestern Colorado. Forest Sci. $21: 912$.

Loucks, O. L. 1970. Evolution of diversity, efficiency and community stability. Amer. Zool. 10:17 25

Madgwick. H. A. I. \& T. Satoo. 1975. On estimating the aboveground weights of tree stands. Ecology 56:1446 1450.

Mälkönen. E. 1975. Annual primary production and nutrient cycle in some Scots Pine stands. Comm. Inst. For. Fenn. 84: $1-87$.

Mealey. S. 1975. The natural food habits of free ranging grizzly bears in Yellowstone National Park. 1973 1974. Thesis Montana State Univ.. Bozeman.

Moir. W. H. 1972. Litter, foliage, branch and stem production in contrasting lodgepole pine habitats of the Colorado Front Range. In : Franklin. J. F.. L. J. Dempster \& R. Waring (eds.), Proceedings Research on Coniferous Forest Ecosystems a Symposium, pp. 189-198. Pac. Northwest Forest and Range Exp. Sta.. Portland, Oregon.

Peattle. D. C. 1953. A natural history of western trees. Houghton Mifflin. Boston. $751 \mathrm{pp}$

Pfister, R. D. 1976. Land capability assessment by habitat types. In: America's Renewable Resource Potential. 1975: The turning point. Proc. 1975 Natl. Conv. Soc. Am. For.. pp. 312-325.

Pfister, R. D.. B. L. Kovalchik. S. F. Arno \& R. C. Presby. 1974. Forest habitat types of Montana. USDA Forest Service. Intermtn. Forest and Range Exp. Sta. Missoula. Montana. $213 \mathrm{pp}$.

Rodin. L. E. \& N. I. Bazilevich. 1967. Production and mineral cycling in terrestrial vegetation. Oliver and Boyd. Edinburgh. London. $288 \mathrm{pp}$

Shinozaki, K.. K. Yoda. K. Hozumi \& T. Kira. 1964. A quantitative analysis of plant form the pipe model theory. Jap. J. Ecol. 14:97-105.

Spurr. S. H. 1952. Forest Inventory. The Ronald Press, New York. $476 \mathrm{pp}$.

Weaver. T. 1974. The growth of two scrub oaks and the cost of their leaves. Proc. Mont. Acad. Sci. 35: 19.23.

Weaver. T. \& D. Dale. 1974. Pinus albicaulis in Central Montana: environment, vegetation and production. Am. Mid. Nat. 92: 222-230

Weaver. T. \& F. Forcella. 1977. Biomass estimates of Northern Rocky Mountain trees and forests. Great Basin Nat. (in press)

Weckwerth, R. 1971. Grizzly bear. In : T. Musselh \& F. Howell (eds.). Game Management in Montana. Montana Fish and Game. Helena. $238 \mathrm{pp}$

Westlake, D. F, 1963. Comparisons of plant productivity. Biol. Rev.. Cambridge Phil. Soc. 38: $385-425$.

Westman. W. E. \& R. H. Whittaker. 1975. The pygmy forest region of northern California: studies on biomass and primary productivity. J. Ecol. 63: 493-520.

Whittaker, R. H. 1966. Forest dimensions and production in the Great Smoky Mountains. Ecology 47: 103-121 
Whittaker, R. H., F. H. Bormann. G. E. Likens \& T. G. Siccama. 1974. The Hubbard-Brook ecosystem study: lorest biomass and production. Ecol. Monogr. 44: 233252.

Whitlaker, R. H. \& P. L. Marks. 1975. Methods of assessing terrestrial productivity. In: H. Lieth \& R. H. Whitlaker (eds.). Primary Productivity of the Biosphere, pp. 55-118. Springer-Verlag, New York.

Whittaker, R. H. \& W. A. Niering. 1975. Vegetation of the Santa Catalina Mountains. Arizona. V. Biomass, production and diversity along the clevation gradient. Ecology 56: 771 791.

Whittaker. R. H. \& G. M. Woodwell. 1968. Dimension and production relations of trees and shrubs in the Brookhaven Forest. New York. J Ecol. 56:1 25.

Yoda, K. 1968. A preliminary survey of the forest vegetation of eastern Nepal. III. Plant biomass in the sample plots chosen from different vegetation zones. J. College Arts Sci.. Chiba Univ. Nat. Sci. Ser. 5: $277-302$.

Zavitkowski. J. \& R. D. Stevens. 1972. Primary productivity of red alder cosystems, Ecology 53: 235 -242.

Accepted 2 March 1977 